Int. J. Dev. Biol. 63: 395-405 (2019)

https://doi.org/10.1387/ijdb.190259rg

\title{
Extracellular signaling in Dictyostelium
}

\author{
KRISTEN M. CONSALVO, RAMESH RIJAL, YU TANG, SARA A. KIROLOS, MORGAN R. SMITH \\ and RICHARD H. GOMER*
}

Department of Biology, Texas A\&M University, College Station, Texas, USA

\begin{abstract}
In the last few decades, we have learned a considerable amount about how eukaryotic cells communicate with each other, and what it is the cells are telling each other. The simplicity of Dictyostelium discoideum, and the wide variety of available tools to study this organism, makes it the equivalent of a hydrogen atom for cell and developmental biology. Studies using Dictyostelium have pioneered a good deal of our understanding of eukaryotic cell communication. In this review, we will present a brief overview of how Dictyostelium cells use extracellular signals to attract each other, repel each other, sense their local cell density, sense whether the nearby cells are starving or stressed, count themselves to organize the formation of structures containing a regulated number of cells, sense the volume they are in, and organize their multicellular development. Although we are probably just beginning to learn what the cells are telling each other, the elucidation of Dictyostelium extracellular signals has already led to the development of possible therapeutics for human diseases.
\end{abstract}

KEY WORDS: chemoattractant, chemorepellent, proliferation regulation, development regulator, secreted factor

\section{Introduction}

As described in other papers in this special issue, Dictyostelium discoideum is a premier system to study a remarkably broad swath of biology. The simplicity, the duality of a single-cell and a multicellular life stage, the ability to freeze cells, the ability to grow mutants that completely block development, and the availability of genetic tools such as REMI and shotgun antisense for genetic screens allow studies that would be exceedingly difficult in other systems. In this short review, we will discuss some of the work done that has helped to elucidate how extracellular signals are used by Dictyostelium, and how these studies have led our understanding of many aspects of the biology of higher eukaryotes. In the following sections, we will describe work on extracellular signals that attract cells toward the source of the signal (chemoattractants), signals that cause cells to move away from the source of the signal (chemorepellents), signals that promote and signals that inhibit proliferation, signals that allow cells to sense their local cell density, and signals that allow cells to sense the local density of specific types of cells.

Abbreviations used in this paper, 8CPT-cAMP, 8-(p-chlorophenylthio)-cyclic adenosine monophosphate; AcbA, acyl-coenzyme A-binding protein A; AprA, autocrine proliferation repressor protein A; ARDS, acute respiratory distress syndrome; ATP, adenosine triphosphate; BzpN, basic-leucine zipper transcription factor N; cAMP or cyclic AMP, 3',5'-cyclic adenosine monophosphate; cAR, cyclic AMP receptor; c-di-GMP, bis-(3'-5')-cyclic dimeric guanosine monophosphate (also known as cyclic-di-GMP); $\mathrm{CF}$, counting factor; $\mathrm{CfaD}$, counting factor-associated protein D; cGMP, cyclic guanosine monophosphate; Cln3, homolog of human ceroid lipofuscinosis neuronal 3; CMF, conditioned medium factor; CnrN, cell number regulator N (PTEN-like phosphatase); CynA, callipygian; DdPpk 1, D. discoideum polyphosphate kinase 1; DhkA, Dictyostelium histidine kinase A; DIC, discoidin-inducing complex; DicAl, discoidin-inducing complex protein Al (also known as DicA or PsiF (prespore inducing factor psiA)); DIF, differentiation-inducing factor; DPPIV, dipeptidyl peptidase IV; ElmoE, engulfment and cell motility E; ERK2, extracellular signal-regulated kinase 2; EV, extracellular vesicles; F-actin, filamentour actin; fAR, folic acid receptor; GABA, gamma-aminobutyric acid; GadA, glutamate decarboxylase A; GrlD, metabotropic glutamate receptor-like D; GrlH, metabotropic glutamate receptor-like H; GTP, guanosine triphosphate; i6kA, inositol hexakisphosphate kinase; IplA, inositol 1,4,5-trisphosphate receptor-like protein A; KrsB, kinase responsive to stress B (also known as Krs2); MAPK, mitogen-activated kinases; PAR2, protease-activated receptor 2; PI3K, phosphoinositide 3-kinase; PIP3, phosphatidylinositol (3,4,5)-trisphosphate; PKA, protein kinase A; PKBA, protein kinase B (also known as Akt); PKBR1, protein kinase B-related kinase 1 (also known as PkgB); PKD2, polycystic kidney disease 2 (also known as TrpP); PSF, pre-starvation factor; PTEN, phosphatase and tensin homolog; REMI, restriction enzyme mediated integration; SAP, serum amyloid P; ScPPX1, Saccharomyces cerevisiae polyphosphate exopolyphosphatase 1; SDF, spore differentiation factor; TagC, tight aggregate protein C; TorC2, target-of-rapamycin complex 2; Trp, transient receptor potential; TrpP, transient receptor potential polycystin-type (also known as PKD2).

*Address correspondence to: Richard H. Gomer. Department of Biology, Texas A\&M University, 301 Old Main Drive, College Station, TX $77843-3474$ USA.

Tel: +1-979-458-5745. Fax: +1-979-845-2891. E-mail: rgomer@tamu.edu - web: www.bio.tamu.edu/wordpress/index.php/lab-website-richard-gomer

(iD) https://orcid.org/0000-0003-2361-4307

Submitted: 20 May, 2019; Accepted: 20 June, 2019.

ISSN: Online 1696-3547, Print 0214-6282

(C) 2019 UPV/EHU Press

Printed in Spain 


\section{Chemoattractants}

Much of the multicellular morphogenesis in an embryo, and the homing of immune cells to a site of inflammation, require cells to crawl toward an attractant. Biased movement of cells in a chemotactic gradient requires signal transduction at the side of the cell closest to the chemoattractant to be different from the same pathway at the opposite side of the cell, and this then causes a rearrangement of cytoskeletal proteins such as actin and myosin to make the cell move toward the attractant (Fig. 1). Much of what we currently know about the molecular mechanisms underlying this sort of directed cell motility in eukaryotes originated from work in Dictyostelium. In Dictyostelium, 3',5'-cyclic adenosine monophosphate (cyclic AMP or cAMP) produced by Dictyostelium cells and folic acid produced by bacteria have been used as paradigms for chemoattractants.

\section{Chemoattraction to cAMP}

Starvation induces the development of Dictyostelium cells (Bonner and Scharf, 1978). The starved cells synthesize and secrete pulses of cAMP, with cells in the regions of highest cell density secreting the first pulses. This causes the temporary formation of an extracellular cAMP gradient around the secreting cell, causing nearby cells to move toward the secreting cell and also to secrete pulses of cAMP, resulting in a propagating wave of cAMP that spreads through a field of cells (Konijn et al., 1967, Philipsborn and Bastmeyer, 2007, Schneider and Haugh, 2006). These waves repeat approximately every 6 minutes (Tomchik and Devreotes, 1981), resulting in cells moving toward a common aggregation center. Upon reaching the aggregation center, they form a multicellular mound that further develops into $\mathrm{a} \sim 2 \times 10^{4}-1 \times 10^{5}$ cell (the number of cells depends on the strain) fruiting body consisting of a mass of spores held off the soil by a thin column of stalk cells.

Similar to neuronal signal transduction where rapid removal of the neurotransmitter is needed at a synapse, to prevent the extracellular cAMP concentration from building up and saturating the cAMP sensing mechanism, aggregating cells also secrete cAMPdegrading phosphodiesterases, and loss of the phosphodiesterase can inhibit aggregation (Franke and Kessin, 1992).

Although the review in this volume on 'Signaling networks during aggregation' by Devreotes et al., and 'Cytoskeleton dynamics during aggregation' by Muller-Taubenberger will discuss cAMP signal transduction in more detail, we will briefly review this, as this work has guided many studies on other extracellular signals. In Dictyostelium, extracellular CAMP is sensed by cell surface receptors (Klein et al., 1988). Four different cAMP receptors, cAR1, cAR2, cAR3 and CAR4, are expressed sequentially during development. These receptors are homologous to 7-transmembrane G protein-coupled receptors found in plants and mammals. Although from the same family of transmembrane proteins, cAR1-4 have different affinities for cAMP (Kim et al., 1998). cAR1 was the first chemoattractant receptor to be identified in eukaryotic cells and is the main receptor that is involved in cAMP chemotaxis (Klein et al., 1988). In a cAMP gradient, the expression of cAR1 receptor is uniformly distributed on the surface of cells. Therefore, cAMP gradient sensing does not require re-localization of cAR1 receptors on the membrane. (Xiao et al., 1997).

A relatively large number of studies have begun to elucidate the signal transduction pathway downstream of the cAMP receptor that regulates the cytoskeleton to cause movement of a cell toward cAMP (Chen et al., 2007, Kortholt et al., 2011). A key lesson from this work is the unexpected complexity of the signal transduction mechanism. One of the earliest steps in the pathway is cAR1 activation of Ras (Kortholt et al., 2011). Active Ras then activates a pathway to cause adenylyl cyclase to synthesize cAMP which is then released to the extracellular environment (Bolourani et al., 2006, Lim et al., 2001). There are at least six different signal transduction pathways downstream of cAMP receptors that mediate chemotaxis. These pathways include PI3K/ PIP3, TorC2, phospholipase A, guanylyl cyclase, MAPK, and ElmoE (Kortholt et al., 2011, Ma et al., 1997, Yan et al., 2012). The pathways promote actin polymerization and pseudopod formation at the side of the cell closest to the source of the extracellular CAMP, and induce myosin contraction at the 'back' of the cell to cause the cell to squeeze itself into the pseudopod. Guided in part by the Dictyostelium work, many workers have found that human neutrophils use very similar pathways and mechanisms (Thomas et al., 2018). Much of the current work in the chemotaxis field involves further elucidation of the pathways, their interactions, and how they regulate the cytoskeleton.

\section{Chemoattraction to cAMP by extracellular vesicles}

Many eukaryotic cells release small extracellular vesicles (EVs) containing proteins, nucleic acids, and lipids, and these EVs can be ingested by neighboring cells as a mode of communication (Iraci et al., 2016, Zaborowski et al., 2015). Dictyostelium cells release EVs that can induce responses in other Dictyostelium cells (Tatischeff, 2019). One of these induced responses is chemotaxis. Aggregating cells release EVs, and the EVs in turn synthesize and secrete cAMP using adenylyl cyclase and stored ATP (Kriebel et al., 2018). Thus as a cell is moving toward an aggregation center, it leaves behind a trail of EVs that can attract other cells. As a following cell comes across an EV, it ingests it, and then is attracted to the next EV along the trail. This can then allow cells that are far from other cells to follow the trail and find the aggregation center (Kriebel et al., 2018).

\section{Chemoattraction to folic acid}

During vegetative growth, Dictyostelium cells move towards bacteria, a preferred food source, and use folic acid released from the bacteria as a chemoattractant (Manahan et al., 2004, Meena and Kimmel, 2016). Two folate receptors have been identified in Dictyostelium, fAR 1 and fAR2. fAR 1 is a G-protein-coupled receptor and is the principal receptor for chemoattraction to folic acid (Pan et al., 2016). The signal transduction pathway downstream of fAR1 may be simpler than the cAMP chemoattraction pathway since key signal transduction pathways necessary for CAMP chemoattraction such as PI3K, TorC2, phospholipase A, and guanylyl cyclase are not necessary for chemoattraction to folic acid (Hadwiger et al., 1994, Kortholt et al., 2011).

\section{Chemorepellents}

Most of the research on chemotaxis has been on chemoattraction. In higher eukaryotes, chemorepulsion probably also plays a role in embryonic development and the movement of immune cells (Fig. 1). There have been several studies on chemorepulsion in axon guidance, but few studies on chemorepulsion of amoeboid 


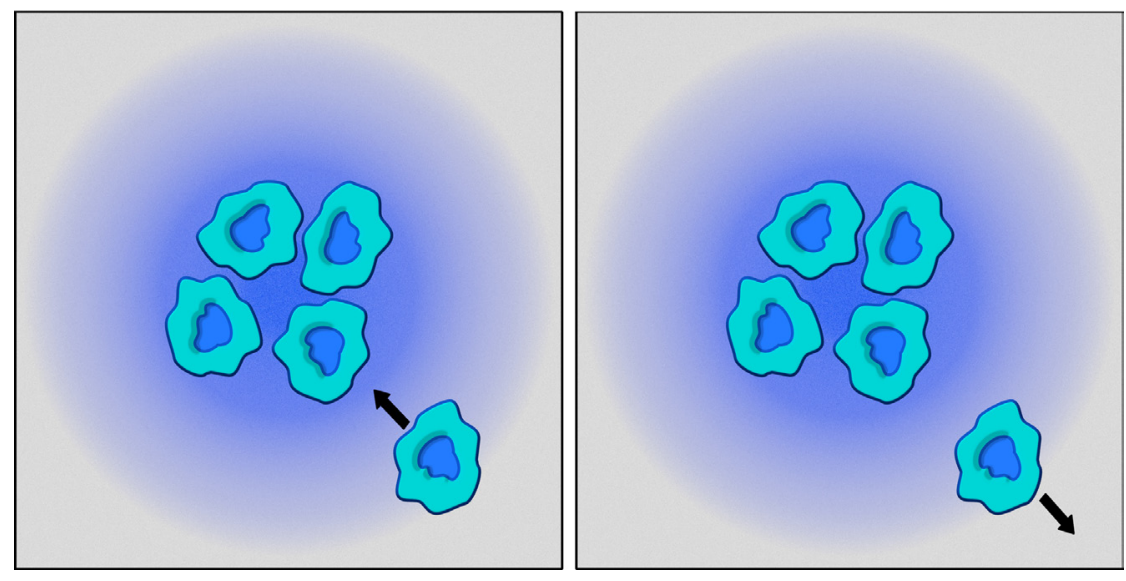

Fig. 1. Chemoattraction and chemorepulsion. If a single cell or a group of cells releases a diffusible factor (blue shading), the high concentration in the vicinity of the releasing cell or cells, and the low concentration far from the source, creates a concentration gradient of the factor. Cells can either be attracted (left) or repelled (right) by the factor. For Dictyostelium and other eukaryotic cells, a concentration difference of a few percent across the cell is sufficient for the cell to sense the gradient.

cells. In Dictyostelium, vegetative cells are repelled by one another, suggesting the presence of endogenous chemorepellents (Samuel, 1961), a synthetic analogue of cAMP can act as a chemorepellent, and a secreted protein called AprA also acts as a chemorepellent. As described below, studies of chemorepulsion in Dictyostelium have led to potential therapeutics for diseases.

\section{Chemorepulsion away from 8CPT-cAMP}

Some synthetic analogues of cAMP that bind to the Dictyostelium cAMP receptor act as antagonists to the receptor. Surprisingly, some of these cAMP analogues such as 8-(p-chlorophenylthio)-cAMP (8CPT-cAMP) repel Dictyostelium cells (Johnson et al., 1992, Van Haastert etal., 1984). Whereas the chemoattractant cAMP causes a pseudopod to form at the front of a cell while simultaneously inducing myosin II localization at the rear, 8CPT-cAMP causes myosin II to first localize at the side of the cell closest to the 8CPT-cAMP, initiating contraction at that side of the cell. F-actin then accumulates at the side of the cell away from the 8CPT-cAMP (Cramer et al., 2018). This suggests that there are fundamental differences in how cells respond to chemoattractants and chemorepellents.

\section{Chemorepulsion away from AprA}

Autocrine proliferation repressor protein A (AprA) is a $60 \mathrm{kDa}$ protein secreted by vegetative cells (Brock and Gomer, 2005, Choe et al., 2009, Phillips and Gomer, 2012). Cells lacking AprA proliferate faster than wild type cells, whereas overexpression of AprA or the addition of recombinant AprA to cultures modestly slows, but does not stop, proliferation (Brock and Gomer, 2005). In the extracellular environment, AprAforms a complex with a protein called CfaD (Choe et al., 2009, Tang et al., 2018). In addition to slowing proliferation, AprA acts as a chemorepellent for vegetative cells (Phillips and Gomer, 2012). Whereas colonies of wild-type cells have many cells moving radially away from the main group of cells, colonies of aprA cells have far fewer cells that have moved away from edge of the group, even though AprA does not affect cell speed, suggesting that a function of AprA is to help disperse colonies of cells, with the high concentration of AprA in the immediate vicinity forming a gradient with the low concentrations of AprA far from the colony.

As with the chemoattractants CAMP and folic acid, AprA is sensed by a G protein coupled receptor called GrlH (Tang et al., 2018). As with chemoattraction to cAMP, AprA also induces Ras activation, and Ras activity is required for AprA-induced chemorepulsion (Rijal et al., 2018). AprA-induced chemorepulsion utilizes components of the TorC2, Phospholipase A, and MAP kinase pathways used for chemoattraction to cAMP, as well as the calcium channel component I plA and protein kinase $\mathrm{C}$. Both phosphatase and tensin homolog (PTEN), which is involved in chemoattraction to cAMP, and the PTENlike protein $\mathrm{CnrN}$ are required for AprA induced chemorepulsion (Herlihy et al., 2013b, Rijal et al., 2018). However, chemorepulsion from AprA does not require other components of the cAMP signal transduction pathway such as guanylyl cyclase, ElmoE, and the PI3K/ PIP3 pathways. Phospholipase $\mathrm{C}$, an essential component of 8CPT-cAMP induced chemorepulsion, is not essential for AprA induced chemorepulsion (Keizer-Gunnink et al., 2007, Phillips and Gomer, 2012, Rijal et al., 2018). Together, these results suggest that chemoattraction and chemorepulsion use partially overlapping sets of signal transduction pathways.

\section{Development of potential therapeutics based on Dictyostelium chemorepulsion}

AprA has very little sequence similarity to any human protein. A tertiary structure of AprA predicted by I-TASSER (Roy et al., 2010, Zhang, 2008), suggested that the AprAstructure might have similarity to human dipeptidyl peptidase IV (DPPIV) (Hiramatsu et al., 2003). Both AprA and DPPIV are glycoproteins, have protease activity, and bind fibronectin (Herlihy etal., 2017). DPPIV is present in plasma and other extracellular fluids (Abbott et al., 1994, Cordero et al., 2009). We found that recombinant human DPPIV functions as a chemorepellent for human neutrophils and Dictyostelium cells (Herlihy et al., 2013a) in gradients encompassing the DPPIV plasma concentration range in mice and humans (Busso et al., 2005, Marguet et al., 2000), which may explain previous observations that abnormally low levels of DPPIV are associated with increased inflammation in mice, rats, and humans (Busso et al., 2005, Kamori et al., 1991, Schmiedl et al., 2010). In humans, acute respiratory distress syndrome (ARDS) is caused by an excessive number of neutrophils in the lungs; similarly, rheumatoid arthritis involves an excessive number of neutrophils in a joint. Being able to repel neutrophils out of the affected tissue might be therapeutic. Treatment with inhaled DPPIV prevented an increase in lung neutrophils in a mouse model of ARDS (Herlihy et al., 2013a), and localized injections of DPPIV decreased symptoms of arthritis in a mouse model (Herlihy et al., 2015). We then found that the DPPIV receptor is the proteaseactivated G protein-coupled receptor PAR 2, that PAR 2 agonists induce human neutrophil chemorepulsion, and when administered by aspiration into the airways, PAR 2 agonists show good efficacy at reducing the inappropriate influx of neutrophils into the lungs in a mouse model of ARDS (White et al., 2018). Together, this suggests 
that chemorepellents based on Dictyostelium work might be useful as therapeutics.

\section{Cell density sensing}

In addition to acting as attractants or repellents, signals can be used to sense the local density of cells. In a closed environment such as the body, if a signal is constitutively released by cells, is able to freely diffuse into the extracellular environment such as the blood, and has a fixed half-life/ degradation rate, the steady state concentration of the signal will be proportional to the number of cells releasing that signal. This can then be used to sense the number of type $X$ cells in a body (Fig. 2). For a small group of cells in an environment such as a soil surface, the local concentration of a diffusible signal will also increase, albeit not linearly, with the number of cells. As described below, studies on Dictyostelium have helped elucidate this type of cell number/ cell density sensing signal.
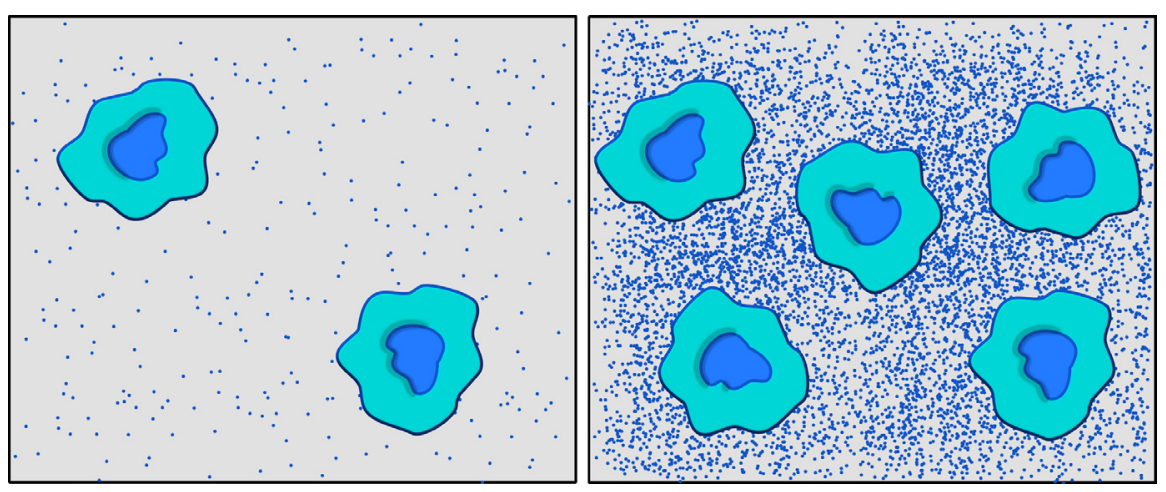

Fig. 2. Cell density sensing (quorum sensing). If cells secrete a diffusible factor (blue dots), the concentration of the factor will increase as the number of cells secreting the factor increases. If cells can sense the concentration of the factor, they can sense the local density of other cells, or for the case of a volatile signal such as ammonia, sense whether they are in a confined space or not. Cells can use this information to regulate their proliferation and thus regulate group or tissue size. Dictyostelium uses cell density sensing factors to anticipate starvation, sense whether a spore is in the spore mass on a fruiting body or has been dispersed and is now an isolated spore, and to decide whether there are too many cells in a stream, and if so to break up the stream into groups of cells.

\section{Cell density sensing signals that regulate cell proliferation}

In higher eukaryotes, growth factors can promote cell proliferation. Typically, one cell type secretes the growth factor, and another cell type responds to the factor. Other factors, called chalones, are secreted by cells, and as the extracellular concentration of the chalone increases, the same cells respond to the chalone by slowing or stopping proliferation. There are many well-studied examples of growth factors. However, despite evidence for their existence, chalones have proven elusive to identify, and there are thus relatively few examples of chalones. As described below, work on Dictyostelium has helped to elucidate chalones, which then led to the development of potential therapeutics.

\section{Growth factor}

Dictyostelium cells in culture proliferate very slowly at low cell densities, and then increase their proliferation rate as the density increases, suggesting that they are either removing a toxin from the medium, or secreting a growth factor whose concentration slowly builds up. A putative growth factor secreted by vegetative Dictyostelium cells is a heat- and detergent- resistant molecule which is sensitive to proteases and reducing agents (Whitbread et al., 1991). These properties are similar to some growth factors in higher eukaryotes such as human platelet-derived growth factor (Heldin et al., 1985).

\section{Proliferation inhibition by AprA and CfaD}

As mentioned above, AprA is a protein secreted during growth. As the cell density increases, the extracellular AprA concentration increases, and at extracellular AprA concentrations equivalent to the concentration reached when the cells are nearing stationary phase, AprA slows but does not stop proliferation for cells grown on bacterial lawns and in shaking culture in axenic growth medium (Brock and Gomer, 2005, Choe et al., 2009). AprA forms a complex with $\mathrm{CfaD}$, a cathepsin-L like protein that does not have protease activity (Bakthavatsalam et al., 2008). Like apr ${ }^{-}$cells, $c f a D^{-}$cells proliferate faster, reach higher stationary phase densities, and then die more quickly than wild type cells (Bakthavatsalam et al., 2008, Brock and Gomer, 2005). CfaD overexpression or addition of recombinant $\mathrm{CfaD}$ slows proliferation, decreases stationary phase density, and increases survival after stationary phase compared to wild type cells (Bakthavatsalam et al., 2008). CfaD does not slow proliferation of apr $A^{-}$cells, and AprA does not slow proliferation of $c f a D^{-}$cells, indicating that the two proteins are essentially message authenticators for each other, possibly to decrease the probability that a signal from the environment might mimic the proliferation inhibition effect of this endogenous signal (Bakthavatsalam et al., 2008, Choe et al., 2009). Cells lacking CIn3, a Dictyostelium homolog of human ceroid lipofuscinosis neuronal3 (CLN3), have decreased extracellular levels of AprA (Huber et al., 2014, McLaren et al., 2019). BzpN, a putative basic leucine zipper transcription factor, is required for the AprA and CfaD proliferation inhibition signal transduction pathway, but not the AprAchemorepulsion pathway, suggesting that a branching pathway mediates AprA chemorepulsion and AprA inhibition of proliferation (Phillips and Gomer, 2012, Phillips et al., 2011). We are currently working to elucidate the two pathways. AprA inhibits cytokinesis more than it inhibits growth (the increase in mass of cells), suggesting that as cell density increases, AprA pushes cells to be, on average, more massive than mid-log phase cells and thus to have more stored nutrients per cell in anticipation of starvation (Brock and Gomer, 2005).

\section{Proliferation inhibition by polyphosphate}

Dictyostelium cells in shaking culture enter a stationary phase when cell density reaches $\sim 2 \times 10^{7}$ cells/ml (Yarger et al., 1974). Adding additional nutrients to stationary phase cells does not rescue the proliferation inhibition, suggesting that the inhibition is not due to a lack of nutrients (Yarger et al., 1974). However, adding conditioned medium from stationary phase cells to mid-log phase cells inhibits their proliferation, indicating the presence of an extracellular prolif- 
eration inhibitor at stationary phase (Yarger et al., 1974). After $\sim 40$ years, the proliferation inhibitor was identified as $\sim 9$-mer inorganic polyphosphate (Suess and Gomer, 2016). The level of extracellular polyphosphate increases with cell density, and reaches $\sim 150 \mu \mathrm{M}$ at stationary phase (Suess and Gomer, 2016). Treating stationary phase conditioned media with the exopolyphosphatase ScPPX1 allows stationary phase cells to proliferate, and adding $150 \mu \mathrm{M}$ polyphosphate to mid log phase cells stops their proliferation (Suess and Gomer, 2016). Polyphosphate inhibits proliferation by affecting cytokinesis more than karyokinesis, causing an increase in cell mass and the number of multinucleate cells (Suess and Gomer, 2016). As with AprA, a possible reason that cells secrete and sense polyphosphate is to anticipate starvation, a condition where larger cells with more stored nutrients would have an advantage over smaller cells, such as cell that have just undergone cytokinesis.

Extracellular polyphosphate levels are regulated by many genes, such as the kinases i6kA and DdPpk1, both of which may directly synthesize polyphosphate (Suess and Gomer, 2016). Cells lacking i6kA or DdPpk1 accumulate less extracellular polyphosphate and reach higher maximum cell densities compared to wild type cells (Suess and Gomer, 2016). Conversely, cells lacking phospholipase D or overexpressing AprA accumulate a higher amount of polyphosphate and have a lower maximum cell density (Suess and Gomer, 2016). This suggests that cells use parameters in addition to cell density to anticipate starvation.

When Dictyostelium cells have decided that they are starving, and there is no reasonable possibility that they might find additional nutrients, they express developmental genes and aggregate to form a fruiting body to disperse cells to new environments. In low nutrient conditions (but not complete starvation), Dictyostelium cells continue to proliferate, albeit slowly. Under these conditions, polyphosphate induces the expression of early development genes and induces aggregation in the presence of nutrients (Suess et al., 2019). Although cells will invariably initiate development if they are completely starved, this suggests that cells can decide to give up on the possibility of finding food, and initiate development, if they observe a combination of low nutrients and high polyphosphate (the latter indicating that there is a local high density of cells, all of which are competing for the limited nutrient resources).

Polyphosphate shows saturable binding to Dictyostelium cells, suggesting the presence of a cell surface polyphosphate receptor, and the receptor was identified as the $G$ protein-coupled receptor GrID (Suess and Gomer, 2016, Suess et al., 2019, Suess et al., 2017). Cells lacking the GrID receptor did not show detectable levels of polyphosphate binding, and expressing GrID in $g r l D^{-}$ cells rescued the binding activity (Suess et al., 2019). In addition to GrID, Ras also mediates polyphosphate-induced aggregation and proliferation inhibition (Suess et al., 2019, Suess et al., 2017). High nutrients appear to override the polyphosphate induction of aggregation, reinforcing the idea that cells integrate multiple sources of information to initiate development.

\section{Development of potential therapeutics based on Dictyostelium chalone work}

Fibrosing diseases such as congestive heart failure, cirrhosis of the liver, end-stage kidney disease, and pulmonary fibrosis are associated with $30-45 \%$ of deaths in the US, and the current best therapeutics only slow the progression (Duffield et al., 2013,
Wynn and Ramalingam, 2012). Fibrosis is due to the inappropriate formation of scar tissue in an internal organ. To help form the scar tissue, circulating monocytes enter the tissue and differentiate into fibroblast-like cells called fibrocytes (Abe et al., 2001, Bucala et al., 1994, Chesney et al., 1997, Chesney et al., 1998). While attempting to purify chalones from human white blood cells, we noticed that monocytes quickly differentiate into fibrocytes in serum-free culture, and that serum inhibits this (Pilling et al., 2003). Since a factor that inhibits fibrocyte differentiation might be useful as a therapeutic for fibrosis, we shifted our focus and, using our experience purifying Dictyostelium secreted factors, purified the fibrocyte-inhibiting factor from human serum and identified it as a protein called serum amyloid P (SAP) (Pilling et al., 2003). We found that injections of SAP could prevent as well as reverse fibrosis in animal models of pulmonary fibrosis (Pilling et al., 2007). We helped form a company called Promedior to pursue this. Promedior found that SAP is an effective therapeutic in 20 different fibrosis models, and SAP showed better efficacy and fewer side effects than current therapeutics in a Phase 1B trial and a 117-patient Phase 2 trial for pulmonary fibrosis, and a Phase 2 trial for myelofibrosis, a bone marrow fibrosis (Dillingh et al., 2013, Raghu et al., 2018). If SAP continues to be effective in further clinical trials, it would be very helpful for fibrosis patients and an example of taking Dictyostelium secreted factor research into the clinic.

\section{Other factors that allow proliferating cells to sense the local cell density}

Proliferating Dictyostelium cells can sense their local cell density using both AprA/CfaD as well as polyphosphate. It is unclear why they need two factors instead of one to do this. Adding to the puzzle, there exist other factors that appear to do the same thing. Discoidin is a lectin that is present at very low levels in cells growing at low cell density, and the levels of discoidin rise as nutrient levels fall and the local cell density increases. Conditioned medium from cells at high cell density added to cells at low cell density induces discoidin expression, indicating the presence of a discoidin-inducing extracellular factor that was named prestarvation factor (PSF) (Clarke and Gomer, 1995, Clarke et al., 1988). As with polyphosphate, the effect of PSF is counteracted by the presence of nutrients. A partial purification of PSF indicated that it is a $\sim 70 \mathrm{kDa}$ protease-sensitive molecule, but PSF was never purified (Burdine and Clarke, 1995). Discoidin-inducing complex (DIC) is an approximately $400 \mathrm{kDa}$ complex that also induces discoidin expression during growth and development (Burdine and Clarke, 1995, Kolbinger et al., 2005). A component of DIC is the $80 \mathrm{kDa}$ protein DicA1 (the sequence of this protein is known), which when added to cells induces discoidin expression, much like PSF. Whether DicA1 is PSF remains unclear. The existence of multiple factors secreted by growing cells that appear to convey the same information (cell density) suggests that the factors may be conveying more complex information, such as the availability of nutrients or the presence of dangers.

\section{Sensing the density of cells in aggregation streams: counting factor}

As described above, if cells decide that their situation is hopeless, they aggregate together to form a fruiting body. The goal of 


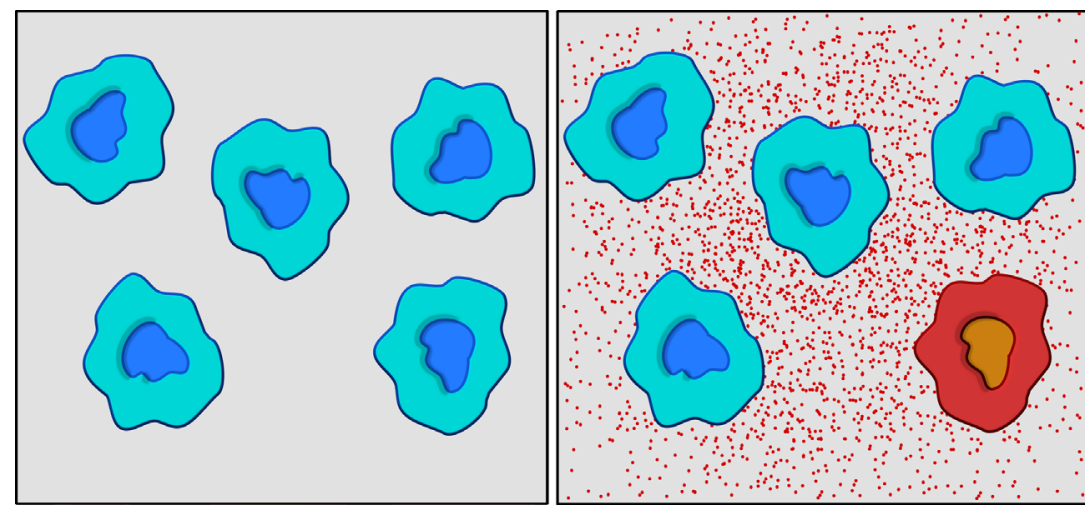

Fig. 3. Sensing the cell type composition of a tissue or group of cells. In addition to general cell density sensing, secreted signals can be used to let a population of cells sense the cell type composition. If cells of a specific subtype $X$ (red cell at right) release a factor characteristic of that subtype (red dots), cells can sense the presence of the subtype. As the percentage of type $X$ cells increases, the concentration of the type $X$ factor increases. If there are no type $X$ cells, there will be no $X$ factor (left panel). Dictyostelium uses such factors to sense stressed cells, starved cells, and to sense the presence of cells that have completed a developmental step and/or differentiation event.

the fruiting body is to raise a mass of spores as high as possible up off the ground to facilitate spore dispersal. If the fruiting body is too small, the spores will be too close to the ground for optimal dispersal, and if the fruiting body is too big, it will collapse. As cells aggregate, they sense their local density in the aggregation streams, and if they sense that there are too many cells in the stream, to prevent too many cells from trying to form a fruiting body, the streams break up into groups, each of which will form a fruiting body. To sense the local density in streams, the cells secrete and sense Counting Factor (CF), a $\sim 450 \mathrm{kDa}$ protein complex (Brock and Gomer, 1999, Roisin-Bouffay et al., 2000). During aggregation, many radial streams of cells flow toward a common center, and the high mass, and thus low diffusivity, of CF would enable each stream to use the local concentration of CF to sense the density of cells in that stream. High levels of CF cause excessive stream breakup and the formation of tiny fruiting bodies, while a lack of functional CF causes large streams to not break up, resulting in huge fruiting bodies that topple over. CF is a complex of four proteins: Countin, CF45-1, CF50, and CF60 (Brock et al., 2003a, Brock and Gomer, 1999, Brock et al., 2002, Brock et al., 2003b, Brock et al., 2006). Disruption of the genes encoding countin, CF45-1, or CF50 block CF function, indicating that as with AprA and CfaD, a complex signal is used to generate 'message authenticators' (Brock et al., 2002, Brock et al., 2003b). Computer simulations predicted, and experiments confirmed, that high levels of CF cause stream breakup by increasing the random motility of cells, and decreasing cell-cell adhesion (RoisinBouffay et al., 2000, Tang et al., 2001). This causes a stream to disperse, much like a liquid to gas phase transition. As the cells disperse and move away from each other, they encounter less of each other's secreted CF, so the extracellular CF concentration at each cell decreases, and the resulting decrease in random motility, and increase in cell-cell adhesion, causes the cells to reform into groups, much like the condensation of a gas into liquid droplets. Aggregates and streams containing few cells will have lower levels of extracellular CF, and this results in the aggregates and streams remaining condensed.

\section{Sensing the density of spores: discadenine}

It is critical that spores germinate to release an amoeba only when they have been dispersed and not when they are in the spore mass atop a fruiting body. To sense the local density of spores, Dictyostelium spores secrete an adenine derivative called discadenine (Nomura et al., 1977, Tanaka et al., 1975). Discadenine promotes spore differentiation and inhibits spore germination (Anjard and Loomis, 2008, Taya et al., 1978).

\section{Sensing the presence of a confining space: ammonia}

To a first approximation, a cell-density sensing/quorum sensing factor measures the ratio of the number of cells to the volume the cells are in, and thus can be used to sense either the cell number in a known volume, or the volume a known number of cells is in. After cells aggregate, they secrete the volatile molecule ammonia, and use this for a variety of purposes, one of which appears to allow cells in a slug to sense whether the slug is in a confined space (such as under a leaf or in soil), as evidenced by a high concentration of ammonia (Bonner et al., 1989, Feit et al., 1990). The ammonia keeps the cells in the migrating slug stage of development. When the slug reaches an open space and senses the concomitant decrease in ammonia, it forms a fruiting body. Ammonia appears to act on cells by affecting the $\mathrm{pH}$ of intracellular compartments (Davies et al., 1993).

\section{Sensing the cell type composition of a tissue}

A longstanding question in developmental biology is how cells sense the composition of a tissue - what the density of type A cells is, what the density of type B cells is, etc. A simple way to do this is for the type A cells to release a type A characteristic factor, and the type $B$ cells to release a type $B$ characteristic factor. The local density of the type A factor would then be indicative of the local density of type A cells (Fig. 3). With the exception of the folic acid secreted by bacteria and the discadenine released by spores, all of the signals described above are released by all cells. In addition to these classes of signals, as described below, Dictyosteliumalso has signals that are released by only some cells. These are paradigms for signals that can be used to sense the composition of a tissue.

\section{A signal saying l'm stressed: extracellular ATP}

When osmotically stressed, Dictyosteliumcells release ATP into the extracellular environment (Sivaramakrishnan and Fountain, 2015). The polycystin-type Trp channel TrpP is either the ATP receptor, or closely coupled to it (Traynor and Kay, 2017). ATP also appears to be sensed by cell surface purinergic receptors that facilitate a rapid increase in intracellular calcium (Ludlow et al., 2008). This results in a reduction in cell swelling due to osmotic stress (Sivaramakrishnan and Fountain, 2015). ATP could thus act as both an autocrine signal to reduce cell swelling and bursting from a sudden reduction in extracellular osmotic strength, and as paracrine signal to let nearby cells know that other cells are also experiencing similar challenges. 


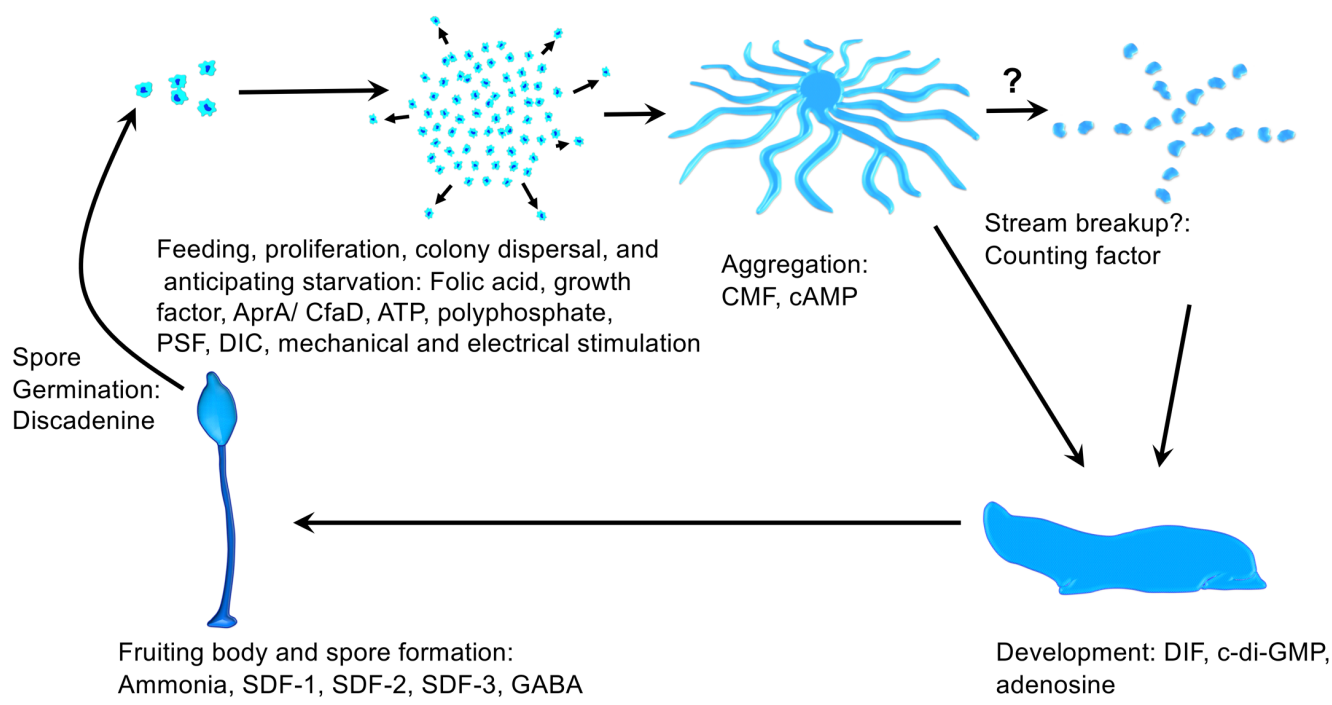

Fig. 4. Involvement of extracellular signaling factors in the Dictyostelium development cycle. The indicated factors play roles at the indicated stages of Dictyostelium development. See text for abbreviations.

\section{A signal saying l'm starving: conditioned medium factor (CMF)}

As discussed above, cells would much rather eat and divide rather than aggregate and form a fruiting body. In a patch of dirt, a cell might be in a small area of a low nutrient environment, with nearby cells still finding food to eat. Knowing whether other nearby cells are also starving will thus let a starving cell know whether it should persist in trying to finding food, or go ahead and participate in aggregation and development. To generate this information, growing cells make and store an $80 \mathrm{kDa}$ glycoprotein called Conditioned Medium Factor (CMF), and then begin slowly secreting CMF when they starve (Gomer et al., 1991, Mehdy and Firtel, 1985). CMF is sensed by cells using an unusual 2-transmembrane receptor, and a G protein-coupled receptor (Deery et al., 2002). At the relatively high extracellular concentrations of CMF indicative of a local high density of starving cells, CMF induces early developmental gene expression, and activates a signal transduction pathway that prolongs the lifetime of the $G$ alpha-GTP protein regulated by the cAMP chemoattraction receptor, allowing chemotaxis to occur (Brazill etal., 1998, Van Haastert etal., 1996). Diffusion calculations showed that in a colony of vegetative cells, if one cell was unable to find food and started secreting CMF while the other cells were still feeding, the concentration of CMF around that one cell would be too low to cause CMF-induced effects (the CMF diffuses away from the cell so quickly that the concentration in the immediate vicinity of the single secreting cell stays quite low), and that only when a majority of the cells in a colony have starved and begun secreting CMF will the extracellular concentration of CMF reach the levels needed to initiate the CMF-induced gene expression and CMF-permitted cAMP signal transduction (Brazill et al., 1997, Yuen and Gomer, 1994, Yuen et al., 1995).

\section{Signals saying l've completed development step X,} so you can now do development step $Y$

Even though the development of Dictyostelium fruiting bodies is one of the simplest examples of a multicellular morphogenesis (to a first approximation, a cylinder of stalk cells supporting a sphere of spore cells), the process does not appear to run automatically, and requires a careful coordination, with checks to make sure that one differentiation event occurs only after a previous event has occurred. If we consider cells that have undergone a differentiation event as a subclass of cells, this then is effectively a subclass of mechanisms that sense the cell type composition of a tissue. Some of these differentiation checks are mediated by cell-cell contact signals, and these signals will be discussed in the chapter on 'Allorecognition' by Gadi Shaulsky. As discussed below, other checks are mediated by secreted signals.

\section{A chlorinated polyketide, cyclic-di-GMP, and adenosine mediate stalk differentiation}

As cells starve, they check what phase of the cell cycle that they happen to be in, and use this information to make the initial choice of whether they will become prespore or prestalk cells (Gomer and Firtel, 1987, Weeks and Weijer, 1994). After cells aggregate, they use a secreted chlorinated polyketide called DIF to regulate the differentiation of prestalk cells to pstO stalk cells (Kay and Jermyn, 1983, Shaulsky and Loomis, 1996, Thompson and Kay, 2000). DIF appears to be made by prespore cells, and thus may be an example of a signal from one cell type/ differentiation stage to initiate the next developmental stage (Brookman et al., 1987). DIF produced by prespore cells at the rear of a slug promotes prestalk cells at the front to produce cyclic-di-GMP (c-di-GMP), also causing the differentiation of prestalk cells into stalk cells (Chen and Schaap, 2016). This exchange of signals would then cause prestalk cells to become stalk cells only when both prespore cells are present, and other prestalk cells are present. Possibly to help spatially segregate the prestalk and prespore cells, extracellular adenosine produced by hydrolysis of secreted CAMP near the prestalk cell-containing tip of the developing fruiting body inhibits prespore cell differentiation (Schaap and Wang, 1986). 


\section{A peptide, a phosphopeptide, GABA, and a steroid mediate spore differentiation}

During the final stages of spore formation and maturation, there is a gradation of gene expression from the bottom to the top of the spore mass, suggesting that diffusible factors mediate spore gene expression and differentiation (Richardson et al., 1994). Three extracellular signals called Spore Differentiation Factors 1, 2, and 3 (SDF-1, SDF-2, and SDF-3) promote spore differentiation. SDF-1 is a thermostable peptide that is phosphorylated by protein kinase A (PKA) and induces spore cell encapsulation (Anjard et al., 1997). SDF-2 is a short peptide cleaved from the acyl-CoA-binding protein (AcbA) by the prestalk cell protease TagC and binds to the receptor histidine kinase DhkA to trigger spore encapsulation (Anjard and Loomis, 2005, Wang et al., 1999). Glutamate decarboxylase (GadA) is expressed specifically in prespore cells during late development and generates GABA from glutamate (Iranfar et al., 2001). GABA induces the release of the SDF-2 precursor AcbA from prespore cells and induces the expression of the protease TagC on the surface of prestalk cells (Anjard and Loomis, 2006). SDF-3 is a steroid which induces the release of GABA (Anjard et al., 2009). This complex series of signals that appear to activate each other thus appear to form a series of checks where the successful completion of one developmental stage permits the next stage to occur.

\section{Other signals: mechanical stimulation}

If a Dictyostelium cell is subjected to mechanical stimuli, a chemotactic response is initiated which allows cells to release focal adhesions at the rear of the cell and induce periodic pseudopod formation at the leading edge (Artemenko et al., 2016, Decave et al., 2003). The plasma membrane calcium channel PKD2 is involved in sensing mechanical stimuli (Lima et al., 2014), and in response to mechanical stimuli, the activity, localization, and concentration of proteins such as ERK2, Ras GTPases, Rac1, KrsB, PKBR1, PIP3, PKBA, PTEN, and CynA are modulated (Artemenko et al., 2016).

\section{Other signals: electrical stimulation}

Electric fields can initiate a chemotactic response in Dictyostelium (Zhao et al., 2006). In Dictyostelium, electric fields are sensed at the membrane by sodium proton exchangers and/or calcium, which induces the recruitment and activation of PI3K, PTEN, and cGMP (Sato et al., 2009, Shanley et al., 2006).

\section{Conclusion}

Dictyostelium cells use a wide variety of signals ranging from ammonia to $450 \mathrm{kDa}$ protein complexes, and these signals play roles at all stages of the Dictyostelium developmental cycle (Fig. 4). The signals fall into the four broad classes of attractants, repellents, general cell density sensing, and subtype cell density sensing. Studying these signals has provided paradigms for similar mechanisms in higher eukaryotes, and has led to potential therapeutics for human diseases.

\section{Acknowledgements}

We thank lan W. Smith for the figures, and Darrell Pilling, Tejas Kar- hadkar, and Shiri Procaccia for comments on the manuscript. This work was supported by NIH GM118355 and GM102280.

\section{References}

ABBOTT, C.A., BAKER, E., SUTHERLAND, G.R. and MCCAUGHAN, G.W. (1994) Genomic organization, exact localization, and tissue expression of the human CD26 (dipeptidyl peptidase IV) gene. Immunogenet. 40: 331-338.

ABE, R., DONNELLY, S.C., PENG, T., BUCALA, R. and METZ, C.N. (2001). Peripheral blood fibrocytes: differentiation pathway and migration to wound sites. J. Immunol. 166: 7556-7562.

ANJARD, C. and LOOMIS, W.F. (2005). Peptide signaling during terminal differentiation of Dictyostelium. Proc Natl Acad Sci USA 102: 7607-7611.

ANJARD, C. and LOOMIS, W.F. (2006). GABA induces terminal differentiation of Dictyostelium through a GABAB receptor. Development 133: 2253-61.

ANJARD, C. and LOOMIS, W.F. (2008). Cytokinins induce sporulation in Dictyostelium. Development 135: 819-827.

ANJARD, C., SU, Y. and LOOMIS, W.F. (2009). Steroids initiate a signaling cascade that triggers rapid sporulation in Dictyostelium. Development 136: 803-812.

ANJARD, C., VAN BEMMELEN, M., VERON, M. and REYMOND, C.D. (1997). A new spore differentiation factor (SDF) secreted by Dictyostelium cells is phosphorylated by the CAMP dependent protein kinase. Differentiation 62: 43-49.

ARTEMENKO, Y., AXIOTAKIS, L., JR., BORLEIS, J., IGLESIAS, P.A. and DEVREOTES, P.N. (2016). Chemical and mechanical stimuli act on common signal transduction and cytoskeletal networks. Proc Natl Acad Sci USA 113: E7500-e7509.

BAKTHAVATSALAM, D., BROCK, D.A., NIKRAVAN, N.N., HOUSTON, K.D., HATTON, R.D. and GOMER, R.H. (2008). The secreted Dictyostelium protein CfaD is a chalone. J Cell Sci 121: 2473-2480.

BOLOURANI, P., SPIEGELMAN, G.B. and WEEKS, G. (2006). Delineation of the roles played by RasG and RasC in cAMP-dependent signal transduction during the early development of Dictyostelium discoideum. Molec. Biol. Cell 17: 4543-4550.

BONNER, J.T., HAR, D. and SUTHERS, H.B. (1989). Ammonia and thermotaxis: Further evidence for a central role of ammonia in the directed cell mass movements of Dictyostelium discoideum. Proc Natl Acad Sci USA 86: 2733-2736.

BONNER, J.T. and SCHARF, D. (1978). Life-Cycle of Cellular Slime-Molds. Natural His. 87: 70-79.

BRAZILL, D.T., GUNDERSEN, R. and GOMER, R.H. (1997). A cell-density sensing factor regulates the lifetime of a chemoattractant-induced $G$ alpha-GTP conformation. FEBS Lett 404: 100-104.

BRAZILL, D.T., LINDSEY, D.F., BISHOP, J.D. and GOMER, R.H. (1998). Cell density sensing mediated by a $\mathrm{G}$ protein-coupled receptor activating phospholipase $\mathrm{C}$. $\checkmark$ Biol Chem 273: 8161-8168.

BROCK, D.A., EHRENMAN, K., AMMANN, R., TANG, Y. and GOMER, R.H. (2003a) Two components of a secreted cell number-counting factor bind to cells and have opposing effects on cAMP signal transduction in Dictyostelium. J Biol Chem 278 : 52262-52272.

BROCK, D.A. and GOMER, R.H. (1999). A cell-counting factor regulating structure size in Dictyostelium. Genes Dev 13: 1960-1969.

BROCK, D.A. and GOMER, R.H. (2005). A secreted factor represses cell proliferation in Dictyostelium. Development 132: 4553-4562.

BROCK, D.A., HATTON, R.D., GIURGIUTIU, D.V., SCOTT, B., AMMANN, R. and GOMER, R.H. (2002). The different components of a multisubunit cell numbercounting factor have both unique and overlapping functions. Development 129 3657-3668.

BROCK, D.A., HATTON, R.D., GIURGIUTIU, D.V., SCOTT, B., JANG, W., AMMANN R. and GOMER, R.H. (2003b). CF45-1, a secreted protein which participates in Dictyostelium group size regulation. Eukaryot Cell 2: 788-797.

BROCK, D.A., VAN EGMOND, W.N., SHAMOO, Y., HATTON, R.D. and GOMER R.H. (2006). A 60-kilodalton protein component of the counting factor complex regulates group size in Dictyostelium discoideum. Eukaryot Cell 5: 1532-1538.

BROOKMAN, J.J., JERMYN, K.A. and KAY, R.R. (1987). Nature and distribution of the morphogen DIF in the Dictyostelium slug. Development 100: 119-124.

BUCALA, R., SPIEGEL, L.A., CHESNEY, J., HOGAN, M. and CERAMI, A. (1994). Circulating fibrocytes define a new leukocyte subpopulation that mediates tissue 
repair. Molec. Med. 1: 71-81.

BURDINE, V. and CLARKE, M. (1995). Genetic and physiologic modulation of the prestarvation response in Dictyostelium discoideum. Mol Biol Cell 6: 311-325.

BUSSO, N., WAGTMANN, N., HERLING, C., CHOBAZ-PÉCLAT, V., BISCHOFDELALOYE, A., SO, A. and GROUZMANN, E. (2005). Circulating CD26 is Negatively Associated with Inflammation in Human and Experimental Arthritis. Am. J. Pathol. 166: 433-442.

CHEN, L., IIJIMA, M., TANG, M., LANDREE, M.A., HUANG, Y.E., XIONG, Y., IGLESIAS, P.A. and DEVREOTES, P.N. (2007). PLA2 and PI3K/PTEN pathways act in parallel to mediate chemotaxis. Dev Cell 12: 603-614.

CHEN, Z.H. and SCHAAP, P. (2016). Secreted Cyclic Di-GMP Induces Stalk Cell Differentiation in the Eukaryote Dictyostelium discoideum. J Bacteriol 198: 27-31.

CHESNEY, J., BACHER, M., BENDER, A. and BUCALA, R. (1997). The peripheral blood fibrocyte is a potent antigen-presenting cell capable of priming naive $T$ cells in situ. Proc. Natl. Acad. Sci. USA 94: 6307-6312.

CHESNEY, J., METZ, C., STAVITSKY, A.B., BACHER, M. and BUCALA, R. (1998). Regulated production of type I collagen and inflammatory cytokines by peripheral blood fibrocytes. J.Immunol. 160: 419-425.

CHOE, J.M., BAKTHAVATSALAM, D., PHILLIPS, J.E. and GOMER, R.H. (2009). Dictyostelium cells bind a secreted autocrine factor that represses cell proliferation. BMC Biochem. 10: 4.

CLARKE, M. and GOMER, R.H. (1995). PSF and CMF, autocrine factors that regulate gene expression during growth and early development of Dictyostelium. Experientia 51: 1124-1134.

CLARKE, M., YANG, J. and KAYMAN, S.C. (1988). Analysis of the prestarvation response in growing cells of Dictyostelium discoideum. Dev Genet 9: 315-326.

CORDERO, O.J., SALGADO, F.J. and NOGUEIRA, M. (2009). On the origin of serum CD26 and its altered concentration in cancer patients. Cancer Immuno Immunother 58: 1723-1747.

CRAMER, L.P., KAY, R.R. and ZATULOVSKIY, E. (2018). Repellent and Attractant Guidance Cues Initiate Cell Migration by Distinct Rear-Driven and Front-Driven Cytoskeletal Mechanisms. Curr Biol 28: 995-1004.e3.

DAVIES, L., SATRE, M., MARTIN, J.B. and GROSS, J.D. (1993). The target of ammonia action in dictyostelium. Cell 75: 321-327.

DECAVE, E., RIEU, D., DALOUS, J., FACHE, S., BRECHET, Y., FOURCADE, B., SATRE, M. and BRUCKERT, F. (2003). Shear flow-induced motility of Dictyostelium discoideum cells on solid substrate. J Cell Sci 116: 4331-4343.

DEERY, W.J., GAO, T., AMMANN, R. and GOMER, R.H. (2002). A single cell densitysensing factor stimulates distinct signal transduction pathways through two different receptors. J Biol Chem 277: 31972-31979.

DILLINGH, M.R., VAN DEN BLINK, B., MOERLAND, M., VAN DONGEN, M.G.J., LEVI, M., KLEINJAN, A., WIJSENBEEK, M.S., LUPHERJR, M.L., HARPER, D.M., GETSY, J.A. et al., (2013). Recombinant human serum amyloid $P$ in healthy volunteers and patients with pulmonary fibrosis. Pulm. Pharmacol. Thera. 26: 672-676

DUFFIELD, J.S., LUPHER, M., THANNICKAL, V.J. and WYNN, T.A. (2013). Host Responses in Tissue Repair and Fibrosis. Annu. Rev. Pathol.: Mech Disease 8: 241-276

FEIT, I.N., BONNER, J.T. and SUTHERS, H.B. (1990). Regulation of the anteriorlike cell state by ammonia in Dictyostelium discoideum. Dev Genet 11: 442-446.

FRANKE, J. and KESSIN, R.H. (1992). The cyclic nucleotide phosphodiesterases of Dictyostelium discoideum: molecular genetics and biochemistry. Cell Signal 4: 471-478.

GOMER, R.H. and FIRTEL, R.A. (1987). Cell-autonomous determination of cell-type choice in Dictyostelium development by cell-cycle phase. Science 237: 758-762.

GOMER, R.H., YUEN, I.S. and FIRTEL, R.A. (1991). A secreted 80 x 10(3) Mr protein mediates sensing of cell density and the onset of development in Dictyostelium. Development 112: 269-278

HADWIGER, J.A., LEE, S. and FIRTEL, R.A. (1994). The G alpha subunit G alpha 4 couples to pterin receptors and identifies a signaling pathway that is essential for multicellular development in Dictyostelium. Proc. Natl. Acad. Sci. USA 91: 10566-10570

HELDIN, C.H., WASTESON, A. and WESTERMARK, B. (1985). Platelet-derived growth factor. Mol Cell Endocrinol 39: 169-187.

HERLIHY, S.E., BROWN, M.L., PILLING, D., WEEKS, B.R., MYERS, L.K. and
GOMER, R.H. (2015). Role of the neutrophil chemorepellent soluble dipeptidy peptidase IV in decreasing inflammation in a murine model of arthritis. Arthritis Rheumatol 67: 2634-2638.

HERLIHY, S.E., PILLING, D., MAHARJAN, A.S. and GOMER, R.H. (2013a). Dipeptidyl peptidase IV is a human and murine neutrophil chemorepellent. J. Immunol. 190: 6468-6477.

HERLIHY, S.E., TANG, Y. and GOMER, R.H. (2013b). A Dictyostelium secreted factor requires a PTEN-like phosphatase to slow proliferation and induce chemorepulsion. PLoS One 8: e59365.

HERLIHY, S.E., TANG, Y., PHILLIPS, J.E. and GOMER, R.H. (2017). Functional similarities between the dictyostelium protein AprA and the human protein dipeptidyl-peptidase IV. Protein Sci 26: 578-585.

HIRAMATSU, H., KYONO, K., HIGASHIYAMA, Y., FUKUSHIMA, C., SHIMA, H., SUGIYAMA, S., INAKA, K., YAMAMOTO, A. and SHIMIZU, R. (2003). The structure and function of human dipeptidyl peptidase IV, possessing a unique eight-bladed beta-propeller fold. Biochem Biophys Res Commun 302: 849-854.

HUBER, R.J., MYRE, M.A. and COTMAN, S.L. (2014). Loss of Cln3 function in the social amoeba Dictyostelium discoideum causes pleiotropic effects that are rescued by human CLN3. PLoS One 9: e110544.

IRACI, N., LEONARDI, T., GESSLER, F., VEGA, B. and PLUCHINO, S. (2016). Focus on Extracellular Vesicles: Physiological Role and Signalling Properties of Extracellular Membrane Vesicles. Int J Mol Sci 17: 171

IRANFAR, N., FULLER, D., SASIK, R., HWA, T., LAUB, M. and LOOMIS, W.F. (2001). Expression patterns of cell-type-specific genes in Dictyostelium. Mol Biol Cell 12: 2590-2600.

JOHNSON, R.L., VAN HAASTERT, P.J., KIMMEL, A.R., SAXE, C.L., 3RD, JASTORFF, B. and DEVREOTES, P.N. (1992). The cyclic nucleotide specificity of three cAMP receptors in Dictyostelium. J Biol Chem 267: 4600-4607.

KAMORI, M., HAGIHARA, M., NAGATSU, T., IWATA, H. and MIURA, T. (1991). Activities of dipeptidyl peptidase II, dipeptidyl peptidase IV, prolyl endopeptidase, and collagenase-like peptidase in synovial membrane from patients with rheumatoid arthritis and osteoarthritis. Biochem Med Metab Biol 45: 154-160.

KAY, R.R. and JERMYN, K.A. (1983). A possible morphogen controlling differentiation in Dictyostelium. Nature 303: 242-244.

KEIZER-GUNNINK, I., KORTHOLT, A. and VAN HAASTERT, P.J.M. (2007). Chemoattractants and chemorepellents act by inducing opposite polarity in phospholipase C and PI3-kinase signaling. J. Cell. Biol. 177: 579-585

KIM, J.Y., BORLEIS, J.A. and DEVREOTES, P.N. (1998). Switching of Chemoattractant Receptors Programs Development and Morphogenesis inDictyostelium:Receptor Subtypes Activate Common Responses at Different Agonist Concentrations. Dev. Biol. 197: 117-128.

KLEIN, P., SUN, T., SAXE, C., KIMMEL, A., JOHNSON, R. and DEVREOTES, P. (1988). A chemoattractant receptor controls development in Dictyostelium discoideum. Science 241: 1467-1472.

KOLBINGER, A., GAO, T., BROCK, D., AMMANN, R., KISTERS, A., KELLERMANN, J., HATTON, D., GOMER, R.H. and WETTERAUER, B. (2005). A cysteine-rich extracellular protein containing a PA14 domain mediates quorum sensing in Dictyostelium discoideum. Eukaryot Cell 4: 991-998.

KONIJN, T.M., VAN DE MEENE, J.G., BONNER, J.T. and BARKLEY, D.S. (1967) The acrasin activity of adenosine-3',5'-cyclic phosphate. Proc. Natl. Acad. Sci. USA 58: 1152-1154

KORTHOLT, A., KATARIA, R., KEIZER-GUNNINK, I., VANEGMOND, W.N., KHANNA A. and VAN HAASTERT, P.J. (2011). Dictyostelium chemotaxis: essential Ras activation and accessory signalling pathways for amplification. EMBO Rep 12 1273-1279.

KRIEBEL, P.W., MAJUMDAR, R., JENKINS, L.M., SENOO, H., WANG, W., AMMU, S., CHEN, S., NARAYAN, K., IIJIMA, M. and PARENT, C.A. (2018). Extracellular vesicles direct migration by synthesizing and releasing chemotactic signals. $J$ Cell Biol 217: 2891-2910.

LIM, C.J., SPIEGELMAN, G.B. and WEEKS, G. (2001). RasC is required for optima activation of adenylyl cyclase and Akt/PKB during aggregation. EMBO J. 20 : 4490-4499.

LIMA, W.C., VINET, A., PIETERS, J. and COSSON, P. (2014). Role of PKD2 in rheotaxis in Dictyostelium. PLoS One 9: e88682.

LUDLOW, M.J., TRAYNOR, D., FISHER, P.R. and ENNION, S.J. (2008). Purinergic- 
mediated Ca2+ influx in Dictyostelium discoideum. Cell Calcium 44: 567-579.

MA, H., GAMPER, M., PARENT, C. and FIRTEL, R.A. (1997). The Dictyostelium MAP kinase kinase DdMEK1 regulates chemotaxis and is essential for chemoattractantmediated activation of guanylyl cyclase. EMBO J. 16: 4317-4332.

MANAHAN, C.L., IGLESIAS, P.A., LONG, Y. and DEVREOTES, P.N. (2004). Chemoattractant signaling in dictyostelium discoideum. Annu Rev Cell Dev Biol20:223-253.

MARGUET, D., BAGGIO, L., KOBAYASHI, T., BERNARD, A.-M., PIERRES, M., NIELSEN, P.F., RIBEL, U., WATANABE, T., DRUCKER, D.J. and WAGTMANN, N. (2000). Enhanced insulin secretion and improved glucose tolerance in mice lacking CD26. Proc. Natl. Acad. Sci. USA 97: 6874-6879.

MCLAREN, M.D., MATHAVARAJAH, S. and HUBER, R.J. (2019). Recent Insights into NCL Protein Function Using the Model Organism Dictyostelium discoideum. Cells 8: 115.

MEENA, N.P. and KIMMEL, A.R. (2016). Biochemical Responses to Chemically Distinct Chemoattractants During the Growth and Development of Dictyostelium. In Chemotaxis: Methods and Protocols, (ed. JIN, T. and HERELD, D.). Springer New York, New York, NY, pp.141-151.

MEHDY, M.C. and FIRTEL, R.A. (1985). A secreted factor and cyclic AMP jointly regulate cell-type-specific gene expression in Dictyostelium discoideum. $\mathrm{Mol}$ Cell Biol 5: 705-713.

NOMURA, T., TANAKAT, Y., ABE, H. and UCHIYAMA, M. (1977). Cytokinin activity of discadenine: A spore germination inhibitor of Dictyostelium discoideum. Phytochem. 16: 1819-1820.

PAN, M., XU, X., CHEN, Y. and JIN, T. (2016). Identification of a Chemoattractant G-Protein-Coupled Receptor for Folic Acid that Controls Both Chemotaxis and Phagocytosis. Dev Cell 36: 428-439.

PHILIPSBORN, A.V. and BASTMEYER, M. (2007). Mechanisms of Gradient Detection: A Comparison of Axon Pathfinding with Eukaryotic Cell Migration. In International Review of Cytology, vol. 263. Academic Press, pp.1-62.

PHILLIPS, J.E. and GOMER, R.H. (2012). A secreted protein is an endogenous chemorepellant in Dictyostelium discoideum. Proc Natl Acad Sci USA 109: 10990-10995

PHILLIPS, J.E., HUANG, E., SHAULSKY, G. and GOMER, R.H. (2011). The putative bZIP transcription factor BzpN slows proliferation and functions in the regulation of cell density by autocrine signals in Dictyostelium. PLoS One 6: e21765.

PILLING, D., BUCKLEY, C.D., SALMON, M. and GOMER, R.H. (2003). Inhibition of fibrocyte differentiation by serum amyloid P. J. Immunol. 17: 5537-5546.

PILLING, D., ROIFE, D., WANG, M., RONKAINEN, S.D., CRAWFORD, J.R., TRAVIS, E.L. and GOMER, R.H. (2007). Reduction of bleomycin-induced pulmonary fibrosis by serum amyloid P. J. Immunol. 179: 4035-4044.

RAGHU, G., VAN DEN BLINK, B., HAMBLIN, M.J., BROWN, A.W., GOLDEN, J.A., HO, L.A., WIJSENBEEK, M.S., VASAKOVA, M., PESCI, A., ANTIN-OZERKIS, D.E. et al., (2018). Effect of Recombinant Human Pentraxin 2 vs Placebo on Change in Forced Vital Capacity in Patients With Idiopathic Pulmonary Fibrosis: A Randomized Clinical Trial. JAMA 319: 2299-2307.

RICHARDSON, D.L., LOOMIS, W.F. and KIMMEL, A.R. (1994). Progression of an inductive signal activates sporulation in Dictyostelium discoideum. Development 120: $2891-900$

RIJAL, R., CONSALVO, K.M., LINDSEY, C.K. and GOMER, R.H. (2018). An endogenous chemorepellent directs cell movement by inhibiting pseudopods at one side of cells. Mol Biol Cell 30: 242-255.

ROISIN-BOUFFAY, C., JANG, W., CAPRETTE, D.R. and GOMER, R.H. (2000). A precise group size in Dictyostelium is generated by a cell-counting factor modulating cell-cell adhesion. Mol Cell 6: 953-959.

ROY, A., KUCUKURAL, A. and ZHANG, Y. (2010). I-TASSER: a unified platform for automated protein structure and function prediction. Nat Protoc 5: 725-738.

SAMUEL, E.W. (1961). Orientation and rate of locomotion of individual amebas in the life cycle of the cellular slime mold Dictyostelium mucoroides. Dev Bio/3:317-335.

SATO, M.J., KUWAYAMA, H., VAN EGMOND, W.N., TAKAYAMA, A.L., TAKAGI, H., VAN HAASTERT, P.J., YANAGIDA, T. and UEDA, M. (2009). Switching direction in electric-signal-induced cell migration by cyclic guanosine monophosphate and phosphatidylinositol signaling. Proc Natl Acad Sci USA 106: 6667-72.

SCHAAP, P. and WANG, M. (1986). Interactions between adenosine and oscillatory CAMP signaling regulate size and pattern in Dictyostelium. Cell 45: 137-144.

SCHMIEDL, A., KRAINSKI, J., SCHWICHTENHÖVEL, F., SCHADE, J., KLEMANN,
C., RABER, K.A., ZSCHEPPANG, K., BEEKMANN, T., ACEVEDO, C., GLAAB, T. et al., (2010). Reduced airway inflammation in CD26/DPP4-deficient F344 rats is associated with altered recruitment patterns of regulatory $T$ cells and expression of pulmonary surfactant proteins. Clin. Exp. Allergy 40: 1794-1808.

SCHNEIDER, I.C. and HAUGH, J.M. (2006). Mechanisms of gradient sensing and chemotaxis: conserved pathways, diverse regulation. Cell Cycle 5: 1130-1134.

SHANLEY, L.J., WALCZYSKO, P., BAIN, M., MACEWAN, D.J. and ZHAO, M. (2006). Influx of extracellular $\mathrm{Ca} 2+$ is necessary for electrotaxis in Dictyostelium. J Cell Sci 119: 4741-4748.

SHAULSKY, G. and LOOMIS, W.F. (1996). Initial cell type divergence in Dictyostelium is independent of DIF-1. Dev Biol 174: 214-220.

SIVARAMAKRISHNAN, V. and FOUNTAIN, S.J. (2015). Evidence for Extracellular ATP as a Stress Signal in a Single-Celled Organism. Eukaryot Cell 14: 775-782.

SUESS, P.M. and GOMER, R.H. (2016). Extracellular Polyphosphate Inhibits Proliferation in an Autocrine Negative Feedback Loop in Dictyostelium discoideum. $J$ Biol Chem 291: 20260-20269.

SUESS, P.M., TANG, Y. and GOMER, R.H. (2019). The putative G protein-coupled receptor GrID mediates extracellular polyphosphate sensing in Dictyostelium discoideum. Mol Biol Cell 30: 1118-1128.

SUESS, P.M., WATSON, J., CHEN, W. and GOMER, R.H. (2017). Extracellular polyphosphate signals through Ras and Akt to prime Dictyostelium discoideum cells for development. J Cell Sci 130: 2394-2404.

TANAKA, Y.-M., HASHIMOTO, Y., YANAGISAWA, K., ABE, H. and UCHIYAMA, M. (1975). Partial Structure of a Spore Germination Inhibitor from a Cellular Slime Mold, Dictyostelium discoideum. Agricul. Biol. Chem. 39: 1929-1932.

TANG, L., AMMANN, R., GAO, T. and GOMER, R.H. (2001). A cell number-counting factor regulates group size in Dictyostelium by differentially modulating cAMPinduced cAMP and cGMP pulse sizes. J Biol Chem 276: 27663-27669.

TANG, Y., WU, Y., HERLIHY, S.E., BRITO-ALEMAN, F.J., TING, J.H., JANETOPOULOS, C. and GOMER, R.H. (2018). An Autocrine Proliferation Repressor Regulates Dictyostelium discoideum Proliferation and Chemorepulsion Using the G Protein-Coupled Receptor GrlH. MBio 9: e02443-17.

TATISCHEFF, I. (2019). Dictyostelium: A Model for Studying the Extracellular Vesicle Messengers Involved in Human Health and Disease. Cells 8: 225.

TAYA, Y., TANAKA, Y. and NISHIMURA, S. (1978). Cell-free biosynthesis of discadenine, a spore germination inhibitor of Dictyostelium discoideum. FEBS Lett 89: 326-328.

THOMAS, M.A., KLEIST, A.B. and VOLKMAN, B.F. (2018). Decoding the chemotactic signal. J Leukoc Biol 104: 359-374.

THOMPSON, C.R. and KAY, R.R. (2000). The role of DIF-1 signaling in Dictyostelium development. Mol Cell 6: 1509-1514.

TOMCHIK, K. and DEVREOTES, P. (1981). Adenosine 3',5'-monophosphate waves in Dictyostelium discoideum: a demonstration by isotope dilution--fluorography Science 212: 443-446.

TRAYNOR, D. and KAY, R.R. (2017). A polycystin-type transient receptor potential (Trp) channel that is activated by ATP. Biol Open 6: 200-209.

VAN HAASTERT, P.J., BISHOP, J.D. and GOMER, R.H. (1996). The cell density factor CMF regulates the chemoattractant receptor CAR1 in Dictyostelium. J Cell Biol 134: 1543-1549.

VAN HAASTERT, P.J., VAN DRIEL, R., JASTORFF, B., BARANIAK, J., STEC, W.J. and DE WIT, R.J. (1984). Competitive cAMP antagonists for cAMP-receptor proteins. J Biol Chem 259: 10020-10024.

WANG, N., SODERBOM, F., ANJARD, C., SHAULSKY, G. and LOOMIS, W.F. (1999). SDF-2 induction of terminal differentiation in Dictyostelium discoideum is mediated by the membrane-spanning sensor kinase DhkA. Mol Cell Biol 19: 4750-4756.

WEEKS, G. and WEIJER, C.J. (1994). The Dictyostelium cell cycle and its relationship to differentiation. FEMS Microbiol Lett 124: 123-130.

WHITBREAD, J.A., SIMS, M. and KATZ, E.R. (1991). Evidence for the presence of a growth factor in Dictyostelium discoideum. Dev Genet 12: 78-81.

WHITE, M.J.V., CHINEA, L.E., PILLING, D. and GOMER, R.H. (2018). Protease activated-receptor 2 is necessary for neutrophil chemorepulsion induced by trypsin, tryptase, or dipeptidyl peptidase IV. J Leukoc Biol 103: 119-128.

WYNN, T.A. and RAMALINGAM, T.R. (2012). Mechanisms of fibrosis: therapeutic translation for fibrotic disease. Nat. Med. 18: 1028-1040.

XIAO, Z., ZHANG, N., MURPHY, D.B. and DEVREOTES, P.N. (1997). Dynamic 
Distribution of Chemoattractant Receptors in Living Cells During Chemotaxis and Persistent Stimulation. J. Cell Biol. 139: 365-374.

YAN, J., MIHAYLOV, V., XU, X., BRZOSTOWSKI, J.A., LI, H. and LIU, L. (2012). A G $\beta \gamma$ effector, ElmoE, transduces GPCR signaling to the actin network during chemotaxis. Dev Cell 22: 92-103.

YARGER, J., STULTS, K. and SOLL, D.R. (1974). Observations on the growth of Dictyostelium discoideum in axenic medium: evidence for an extracellular growth inhibitor synthesized by stationary phase cells. J Cell Sci 14: 681-690.

YUEN, I.S. and GOMER, R.H. (1994). Cell density-sensing in Dictyostelium by means of the accumulation rate, diffusion coefficient and activity threshold of a protein secreted by starved cells. J Theor Biol 167: 273-282.
YUEN, I.S., JAIN, R., BISHOP, J.D., LINDSEY, D.F., DEERY, W.J., VAN HAASTERT, P.J. and GOMER, R.H. (1995). A density-sensing factor regulates signal transduction in Dictyostelium. J Cell Biol 129: 1251-162.

ZABOROWSKI, M.P., BALAJ, L., BREAKEFIELD, X.O. and LAI, C.P. (2015). EXtracellular Vesicles: Composition, Biological Relevance, and Methods of Study. Bioscience 65: 783-797.

ZHANG, Y. (2008). I-TASSER server for protein 3D structure prediction. BMC Bioinformatics 9: 40.

ZHAO, M., SONG, B., PU, J., WADA, T., REID, B., TAI, G., WANG, F., GUO, A., WALCZYSKO, P., GU, Y. et al., (2006). Electrical signals control wound healing through phosphatidylinositol-3-OH kinase-gamma and PTEN. Nature442: 457-460. 


\section{Further Related Reading, published previously in the Int. J. Dev. Biol.}

Deletion of etoposide-induced 2.4 kb transcript (ei24) reduced cell proliferation and aggregate-size in Dictyostelium discoideum Neha Gupta and Shweta Saran

Int. J. Dev. Biol. (2018) 62: 273-283

https://doi.org/10.1387/ijdb.170327ss

YelA, a putative Dictyostelium translational regulator, acts as antagonist of DIF-1 signaling to control cell-type proportioning Yoko Yamada, Chris Sugden and Jeffrey G. Williams

Int. J. Dev. Biol. (2017) 61: 35-42

https://doi.org/10.1387/ijdb.160160yy

The Dictyostelium prestalk inducer DIF-1 directs phosphorylation of a bZIP transcription factor

Yoko Yamada, Yuzuru Kubohara, Haruhisa Kikuchi, Yoshiteru Oshima, Hong-Yu Wang, Susan

Ross and Jeffrey G. Williams

Int. J. Dev. Biol. (2013) 57: 375-381

https://doi.org/10.1387/ijdb.130046jw

An orthologue of the Myelin-gene Regulatory Transcription Factor regulates Dictyostelium prestalk differentiation

Hiroshi Senoo, Hong-Yu Wang, Tsuyoshi Araki, Jeffrey G. Williams and Masashi Fukuzawa Int. J. Dev. Biol. (2012) 56: 325-334

https://doi.org/10.1387/ijdb.120030jw

Identification of a target for CudA, the transcription factor which directs formation of the Dictyostelium tip organiser

Hong-Yu Wang and Jeffrey G. Williams

Int. J. Dev. Biol. (2010) 54: 161-165

https://doi.org/10.1387/ijdb.082723hw

Identification of new modes of Dd-STATa regulation of gene expression in Dictyostelium by in situ hybridisation

Nao Shimada, Mineko Maeda, Hideko Urushihara and Takefumi Kawata

Int. J. Dev. Biol. (2004) 48: 679-682

http://www.intjdevbiol.com/web/paper/041862ns

Dictyostelium discoideum: a model system for differentiation and patterning

$\mathrm{R}$ Escalante and $\mathrm{J} \mathrm{J}$ Vicente

Int. J. Dev. Biol. (2000) 44: 819-835

http://www.intjdevbiol.com/web/paper/11206323
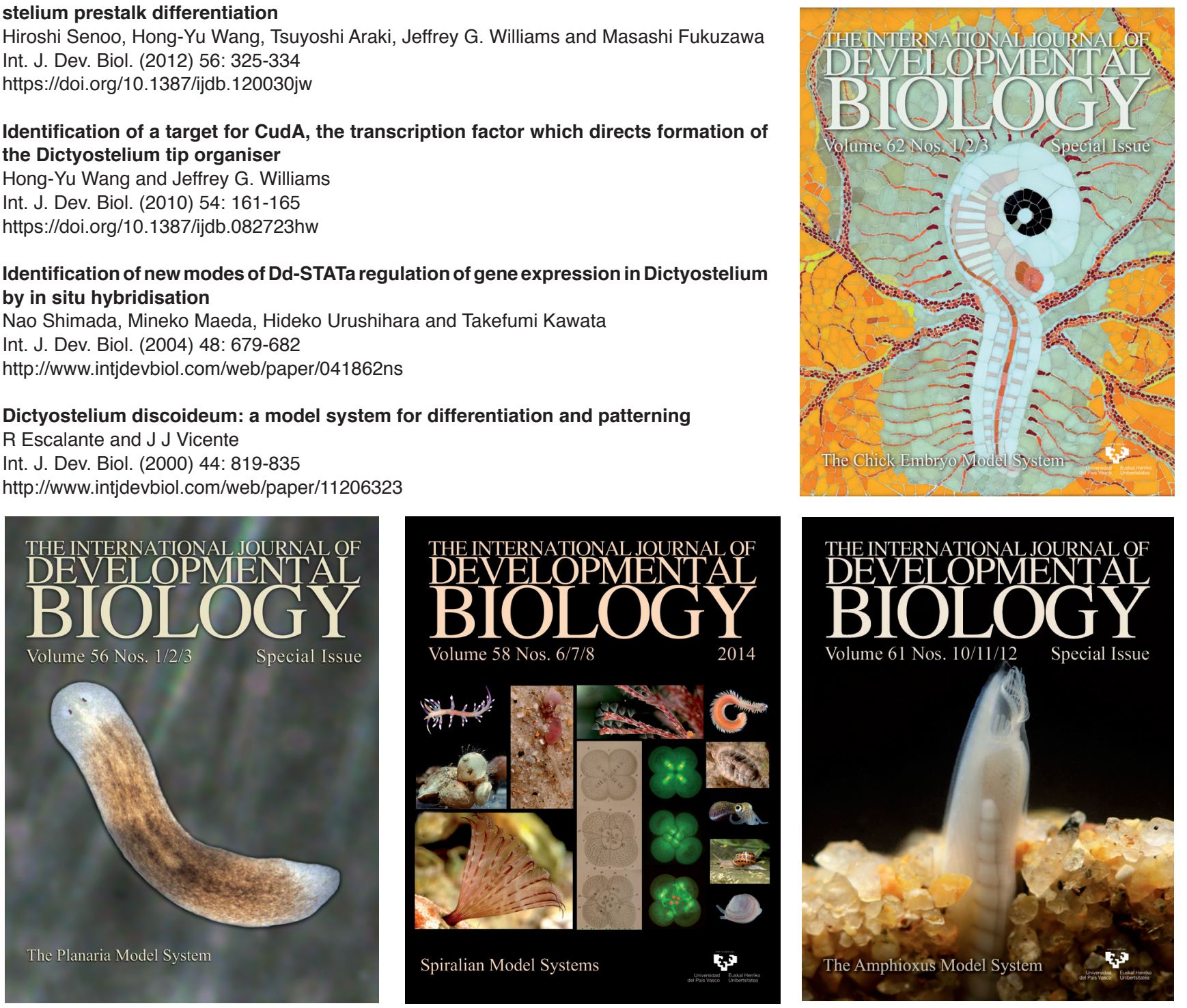